Volume 8, No. 9,November-December 2017

International Journal of Advanced Research in Computer Science

RESEARCH PAPER

Available Online at www.ijarcs.info

\title{
VIRTUAL MACHINE MIGRATION: A COMPARATIVE STUDY
}

\author{
Varun Jasuja \\ Ph.D (Research Scholar), CSE \\ IKGPTU, Jalandhar, India
}

\author{
Rajesh Kumar Singh \\ Professor and Principal, CSE \\ SUS Institute of Computer
}

\begin{abstract}
Usage of virtualization in cloud computing is acquiring more significance because of the lack of appropriate usage of resources, inappropriate load balancing of executing nodes, level of fault tolerance in VMs for increasing the nodes portability and to increase the physical server cost effectively. Therefore, migration is considered as one of the significant features of VM technology. VMM is the migration of VM from single host to other. It is generally executed by post-copy and pre-copy migration. This paper dealt with the reviewing the concept of virtualization following its types. There are different VMM techniques that are also discussed with its comparison. There are challenges, like low bandwidth, fault network, the memory state among clusters. For the enhancement purpose, different optimization as well as classification algorithms has been discussed. Number of authors has worked in the field of virtualization in cloud computing. Few of that are given in the review.
\end{abstract}

Keywords:cloud computing; virtualization;virtual machine migration; service models

\section{INTRODUCTION}

Cloud computing is used to provide services to the users that are connected through internet [1]. The services are accessed by the user from the data that is stored into the server which is generally known as Cloud. Cloud helps to resolve the problems related to network connections and online services [2].Cloud computing can be categorized as a new paradigm for the Dynamic configuration that supports computing services which is usually supported by the data center along with virtual machine [3].Cloud computing provides infrastructure, platforms,and software (application) as available on the paid instant mode. These services are in the industry known as the infrastructure as a service (IaaS), the platform as a Service (PaaS) and software as a service (SaaS) [4]. Many computing service providers include Google, Microsoft, Yahoo, IBM's rapid deployment of data centers at diffeyrent locations providing cloud computing services worldwide [5]. Below table is depicting the service models following its paradigms, features, advantages as well as disadvantages.

Table1.Comparison of service models in cloud computing

\begin{tabular}{|c|c|c|c|c|}
\hline Service model & Paradigm & Features & Advantages & Disadvantages \\
\hline \multirow{8}{*}{$\begin{array}{l}\text { Infrastructure as a } \\
\text { Service (IaaS) }\end{array}$} & \multirow{8}{*}{$\begin{array}{l}\text { Infrastructure as an } \\
\text { resource }\end{array}$} & Platform independent & Scalability & \multirow{5}{*}{$\begin{array}{l}\text { The efficiency } \\
\text { and productivity } \\
\text { of the business } \\
\text { mainly depends } \\
\text { upon the vendor's } \\
\text { ability }\end{array}$} \\
\hline & & Less infrastructure cost & Nil investment & \\
\hline & & \multirow{6}{*}{ Less SLA } & in hardware & \\
\hline & & & Pay per costing & \\
\hline & & & \multirow{4}{*}{$\begin{array}{l}\text { Position } \\
\text { independent }\end{array}$} & \\
\hline & & & & Long term cost \\
\hline & & & & $\begin{array}{l}\text { Require new } \\
\text { centralization }\end{array}$ \\
\hline & & & & $\begin{array}{l}\text { Various security } \\
\text { measure }\end{array}$ \\
\hline \multirow[t]{6}{*}{$\begin{array}{c}\text { Platform as a Service } \\
\text { (PaaS) }\end{array}$} & \multirow[t]{6}{*}{ License purchasing } & $\begin{array}{c}\text { Depend on cloud } \\
\text { infrastructure }\end{array}$ & \multirow{2}{*}{$\begin{array}{c}\text { Scripting } \\
\text { environment } \\
\text { on server side } \\
\end{array}$} & \multirow{3}{*}{$\begin{array}{l}\text { No control over } \\
\text { the VM thus } \\
\text { increasing } \\
\text { security risk }\end{array}$} \\
\hline & & \multirow{5}{*}{$\begin{array}{l}\text { Used by Agile project } \\
\text { management methods }\end{array}$} & & \\
\hline & & & \multirow{4}{*}{$\begin{array}{c}\text { Database } \\
\text { management } \\
\text { system } \\
\text { (DBMS) } \\
\text { Storage } \\
\text { Network } \\
\text { access }\end{array}$} & \\
\hline & & & & \multirow{2}{*}{$\begin{array}{l}\text { Time consuming } \\
\text { as the updating } \\
\text { and upgrading of } \\
\text { application is } \\
\text { done on time }\end{array}$} \\
\hline & & & & \\
\hline & & & & $\begin{array}{c}\text { Less cost } \\
\text { effective than } \\
\text { SaaS }\end{array}$ \\
\hline $\begin{array}{c}\text { Software as a Service } \\
\text { (SaaS) }\end{array}$ & $\begin{array}{l}\text { Software as an } \\
\text { resource }\end{array}$ & $\begin{array}{l}\text { Provide a complete } \\
\text { platform to the user }\end{array}$ & $\begin{array}{l}\text { Administration } \\
\text { is easy }\end{array}$ & $\begin{array}{l}\text { No control over } \\
\text { the data }\end{array}$ \\
\hline
\end{tabular}




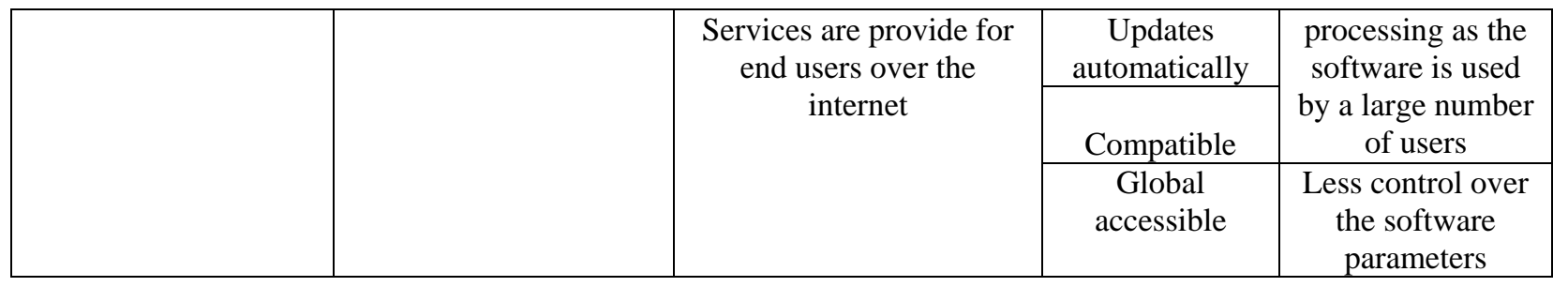

The main technology behind cloud computing is virtualization. Virtualization makes pooling resources which help to utilize resources efficiently with reasonable cost to users.

\section{A. Virtualization}

Virtualization is software that provides a mean to run many operating system (OS) and applications on a single server at same time [6]. Virtualization helps to reduce IT cost and thus, increasing the efficiency of the computer hardware. The technology behind virtualization is called a virtual machine monitor (VMM) or a virtual manager that separates the computing environment from physical infrastructure. Virtualization are mainly categorized into four types namely hardware virtualization, operating system virtualization, server virtualization and storage virtualization [7]. Below figure is showing architecture of virtualization.

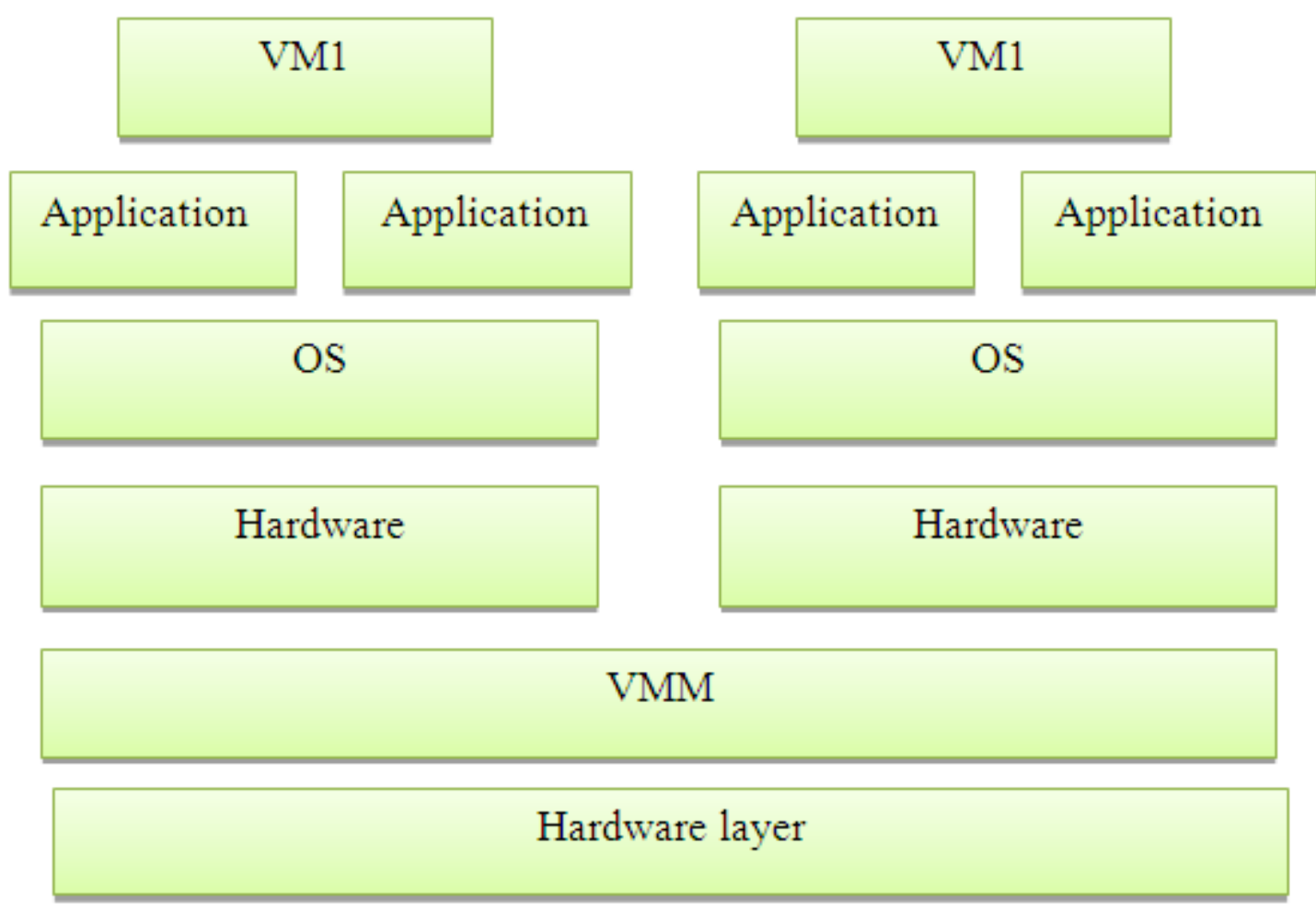

Figure.1.Virtualization Architecture

Virtualization has number of types, namely, hardware, operating system, server virtualization and storage virtualization. The table is depicting the description and the applications [8].

Table 2. Types of Virtualization

\begin{tabular}{|c|c|c|}
\hline $\begin{array}{c}\text { Virtualization } \\
\text { types }\end{array}$ & Definition & Applications \\
\hline $\begin{array}{c}\text { Hardware } \\
\text { virtualization }\end{array}$ & $\begin{array}{c}\text { Virtual machine software and VMM are } \\
\text { directly implemented on the hardware }\end{array}$ & $\begin{array}{c}\text { Mostly used for the server platforms, } \\
\text { because to control a virtual machine is } \\
\text { easier than a physical machine }\end{array}$ \\
\hline $\begin{array}{c}\text { Operating system } \\
\text { virtualization }\end{array}$ & $\begin{array}{c}\text { Virtual machine software and VMM is } \\
\text { implemented on the Host OS }\end{array}$ & $\begin{array}{c}\text { Used for testing the applications on various } \\
\text { platform of OS }\end{array}$ \\
\hline $\begin{array}{c}\text { Server } \\
\text { virtualization }\end{array}$ & $\begin{array}{c}\text { Virtual machine software and VMM is } \\
\text { implemented on the server system }\end{array}$ & $\begin{array}{c}\text { Since the physical server is divided into } \\
\text { many small servers as per the demand of } \\
\text { the user thus for load balancing server } \\
\text { virtualization is used }\end{array}$ \\
\hline
\end{tabular}




\begin{tabular}{|c|c|c|}
\hline $\begin{array}{c}\text { Storage } \\
\text { virtualization }\end{array}$ & $\begin{array}{c}\text { A number of network storage devices are } \\
\text { integrated to form a single storage device }\end{array}$ & Mostly used for backup and recovery \\
\hline
\end{tabular}
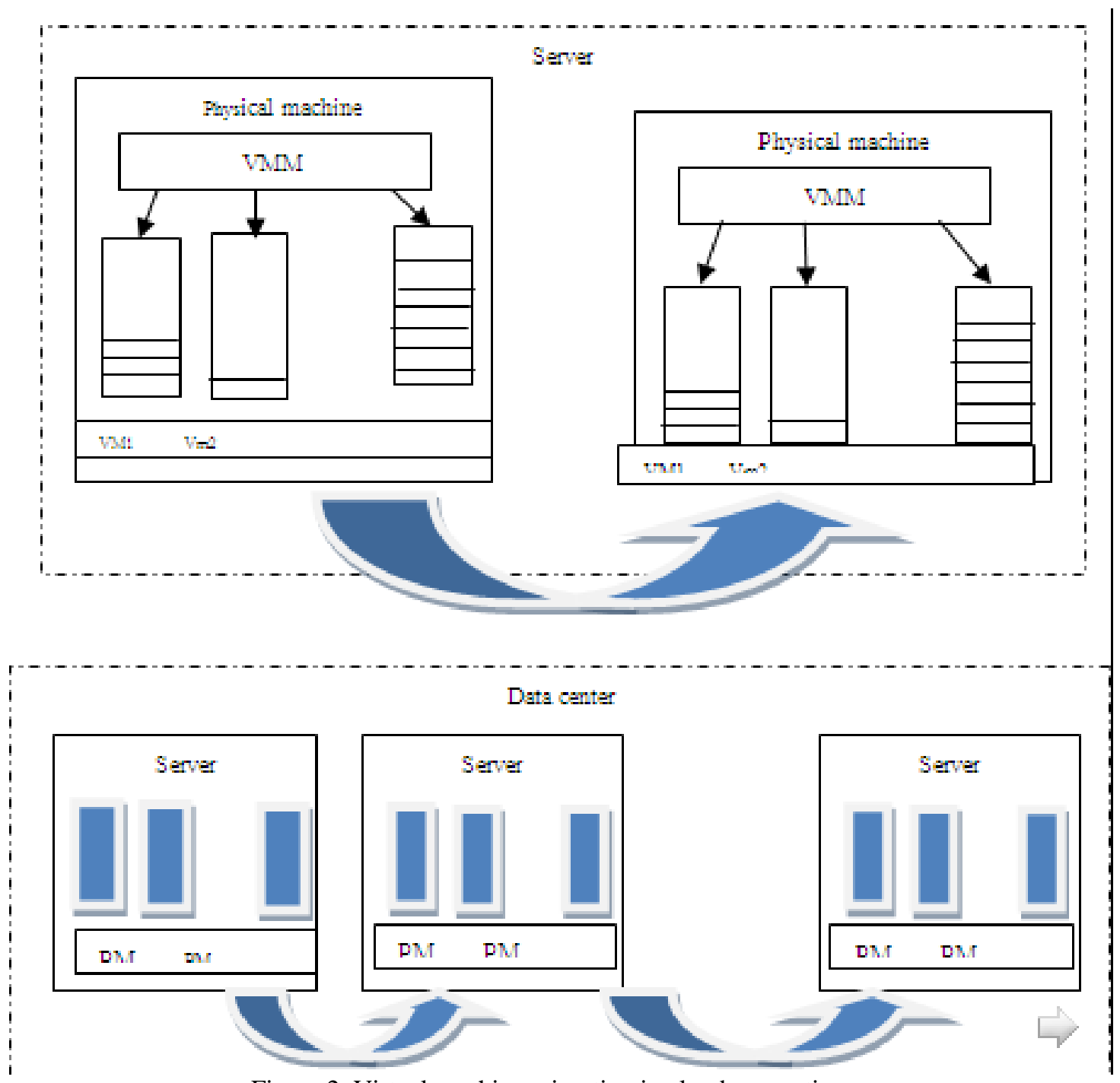

Figure 2. Virtual machine migration in cloud computing

\section{B. Virtual machine migration}

It is the process to migrate virtual machines from one physical machine to another without disconcerting the services provided to the user [9]. It is mainly categorized into two types [10]:

a) Non-Live Virtual Migration: It is also known as off line virtual migration. In this migration process, the VM's on source side is paused and forwarding all the states to the destination and finally, stopped the operation of virtual machine at the target host. The main disadvantage of VM migration is that the downtime is usually higher.

b) Live Virtual Migration: In this migration process, Virtual machines are transferred from one node to another node without disturbing the service.
The live virtual machine migration is mainly divided into two types namely, pre-copy memory migration and post copy memory migration.

- Pre copy memory migration: In this process, memory is transferred initially and then execution is transferred. In this process, memory is transferred from source to destination node over a number of iterations. It mainly works in two phases, namely, warm up phase and stop and copy phase [11]. In warm up phase if the copied page required some changes, then the page is copied again and again until the reduplication rate is less than the moving page rate. In stop and copy mode, the VM's are stopped at the source node, and the left data will be forwarded to the destination node. 


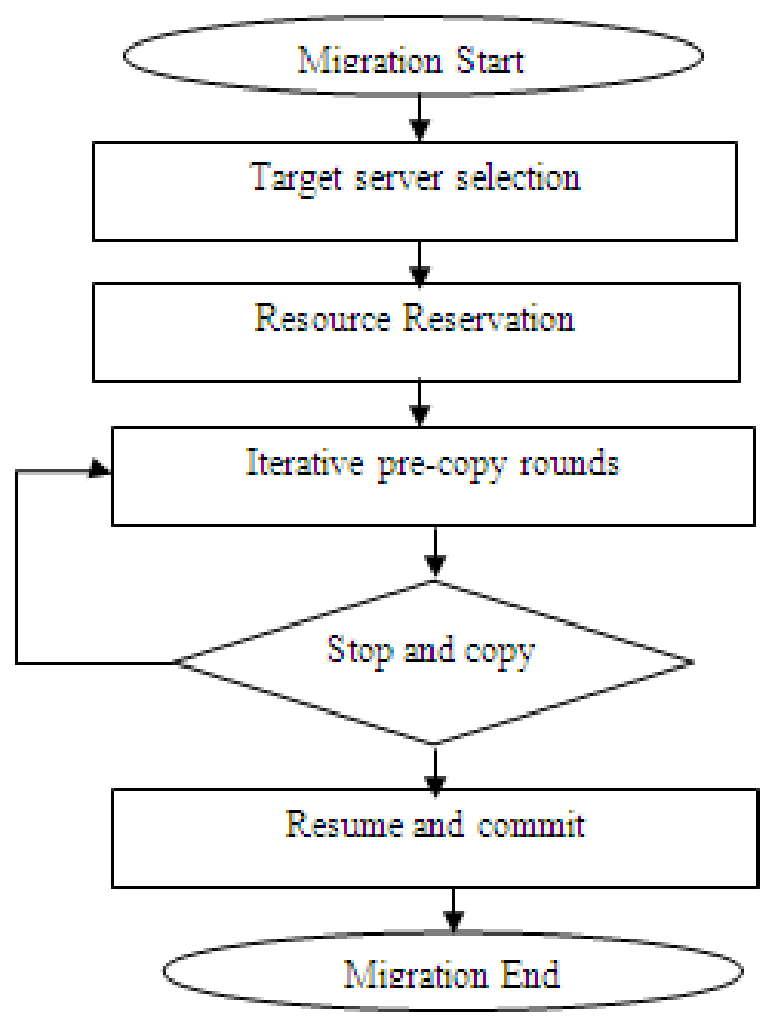

Figure 3. Pre-copy migration

- Post copy: In the post-copy approach, if migration fails, the VM is stopped at the source host and switches the execution states at destination host to resume the VM. After that, copy the memory pages via network links. The VM at destination host start responding immediately [12].

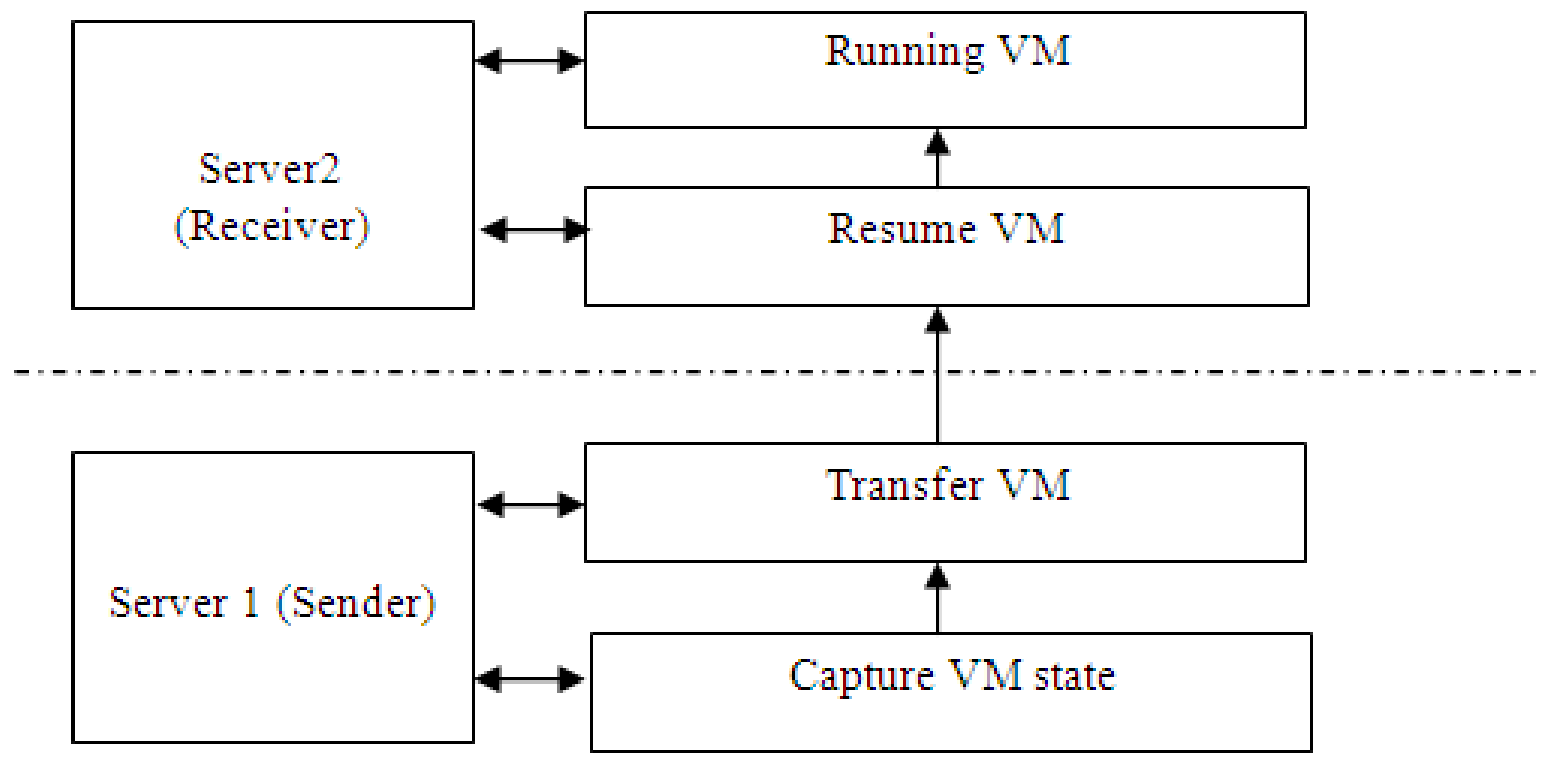

Fig.ure 4. Post copy Migration

- Hybrid algorithm: Firstly, at source, required memory pages migrated in pre-copy phase, then the execution states will be interchanged and VM resumed at destination host. After that, the remaining memory pages will be processed by post-copy algorithm via network link [13]. Fewer numbers of pages need to be accessed from the source, thus, this leads to increase the performance. Total migration time is also better than pre-copy and post-copy approach. It divides mainly into five phases as shown in fig below. 


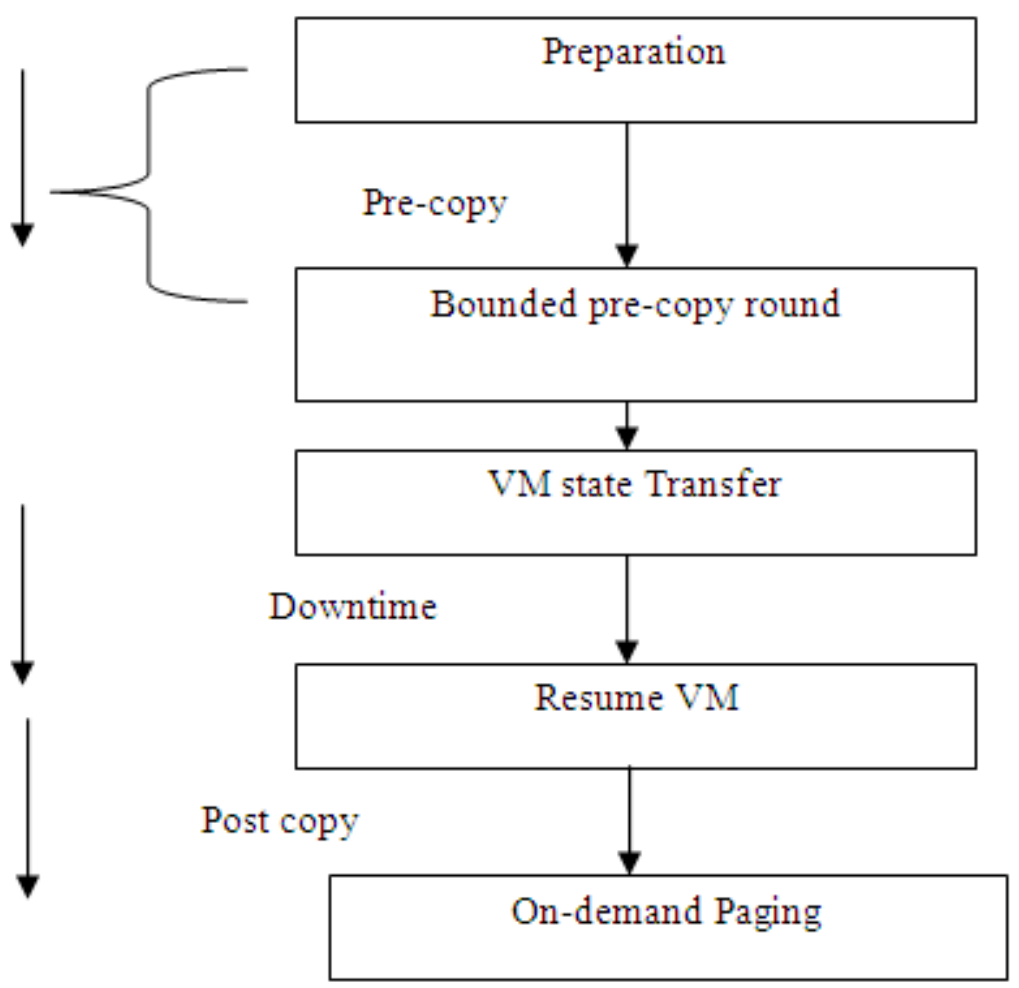

Figure 5. Hybrid VM Migration

i. Preparation phase: In this phase, system resources are reserved at the target host.

ii. Bounded pre-copy rounds:Identify the delimiter precopy phase and transfers the virtual machines from the sender's server to the recipient's server.

iii. VM resume phase:It launches the transferred state at receiver side.

iv. On demand paging:As per the user requirement it sends the application.

The parameters that are considered during the VM migration are [14]:

i. Downtime:It is defined as the time below which no service is available to virtual machines. ii. Migration Time:It is the total time required to transfer a virtual machine from source to destination without any disturbance to the network.

iii. Preparation time:The time between the starting of migration process and virtual machine (VM) processing state is transferred to the destination host, during which the virtual machine run regularly and creates page faults is known as preparation time.

iv. Application Degradation:During the migration process of virtual machine from one node to another, the performance of the services is degraded that is executed at that virtual machine.

Table 3. Comparative analysis of different Virtual machine migration techniques

\begin{tabular}{|c|c|c|c|}
\hline VM migration & Techniques & Advantages & Disadvantages \\
\hline \multirow{6}{*}{ Non-Live } & $\begin{array}{l}\text { Stop VM at source node and } \\
\text { then transfer to destination }\end{array}$ & Simple and easy to use & Require more down time \\
\hline & \multirow[t]{2}{*}{ Pre-copy method } & $\begin{array}{l}\text { Downtime is less than a } \\
\text { second }\end{array}$ & \multirow[t]{2}{*}{$\begin{array}{c}\text { Copied transmission } \\
\text { overhead }\end{array}$} \\
\hline & & $\begin{array}{l}\text { Migration is totally transparent } \\
\text { to the application, OS and } \\
\text { remote customers. }\end{array}$ & \\
\hline & Adaptive rate limiting method & $\begin{array}{l}\text { Service downtime is low } \\
<60 \mathrm{~ms}\end{array}$ & $\begin{array}{l}\text { Total migration time is } \\
\text { low }\end{array}$ \\
\hline & \multirow[t]{2}{*}{ Post -copy method } & $\begin{array}{l}\text { Every memory page is } \\
\text { transmitted only at once }\end{array}$ & \multirow[t]{2}{*}{$\begin{array}{l}\text { Downtime is more as } \\
\text { compared to pre-copy }\end{array}$} \\
\hline & & Less overhead & \\
\hline
\end{tabular}




\begin{tabular}{|c|c|c|c|}
\hline \multirow{3}{*}{$\begin{array}{c}\text { Other } \\
\text { approaches }\end{array}$} & $\begin{array}{l}\text { CPU scheduling and recovering } \\
\text { system }\end{array}$ & $\begin{array}{l}\text { It works on CPU scheduling } \\
\text { and recovering system } \\
\text { Decrease the downtime as well } \\
\text { as total migration time when } \\
\text { compared with pre-processing } \\
\text { techniques }\end{array}$ & $\begin{array}{l}\text { Does nr work well in } \\
\text { more complex system }\end{array}$ \\
\hline & \multirow[t]{2}{*}{$\begin{array}{l}\text { Check pointing/recovery and } \\
\text { trace/ replay approach }\end{array}$} & $\begin{array}{l}\text { VM migration is fast and } \\
\text { transparent }\end{array}$ & \multirow{2}{*}{$\begin{array}{l}\text { This technique is used } \\
\text { only when the replay rate } \\
\text { is larger than the log } \\
\text { growth rate }\end{array}$} \\
\hline & & $\begin{array}{l}\text { The migration and down time } \\
\text { of the system are decreased } \\
\text { totally }\end{array}$ & \\
\hline
\end{tabular}

\section{CHALLENGES IN LIVE VIRTUAL MACHINE MIGRATION}

Live migration has number of challenges as shown in table 4. The challenges considered are; Low bandwidth, Fault network, Memory intensive applications, memory state between clusters and security [15].

Table 4. VMM challenges

\begin{tabular}{|c|c|}
\hline Challenges & Description \\
\hline Low bandwidth & $\begin{array}{c}\text { To transmit the images with large size VM need large bandwidth to allocate the } \\
\text { images }\end{array}$ \\
\hline Fault network & $\begin{array}{l}\text { In post copy technique, when VM tried to fetch pages from destination node that are } \\
\text { not being transferred, it moves back to the source host thus creating network faults } \\
\text { by suspending the VM at source node }\end{array}$ \\
\hline $\begin{array}{l}\text { Memory intensive } \\
\text { applications }\end{array}$ & Decrease the overhead of post copy migration method \\
\hline $\begin{array}{l}\text { Memory state between } \\
\text { clusters }\end{array}$ & $\begin{array}{l}\text { It become a challenge to transfer the control of memory and CPU between the host } \\
\text { system }\end{array}$ \\
\hline Security & The external attack such as Denial of service (DoS) directly affects the VM manager. \\
\hline
\end{tabular}

\section{ALGORITHMS USED IN THE EXISTING WORK}

In this section, we are discussing the algorithms and techniques used in the existing works for virtual migration in cloud computing [16]. The algorithms are GA, PSO, ACO, ABC, ANN and Fuzzy Logic.

Table 5. Comparative analysis of algorithm used in VM migration

\begin{tabular}{|c|c|}
\hline Algorithms & Description \\
\hline \multirow[t]{4}{*}{ Genetic Algorithm (GA) } & GA is inspired from the fitness function via evolution. \\
\hline & There are chromosomes that can be represented in the form of elements known as genes. \\
\hline & It generally works with the chromosome (solution) arbitrary population. \\
\hline & $\begin{array}{l}\text { General parameters used for the simulation in GA are: Number of general, cross over, } \\
\text { population size and mutation. }\end{array}$ \\
\hline \multirow{4}{*}{$\begin{array}{c}\text { Particle Swarm } \\
\text { optimization (PSO) }\end{array}$} & $\begin{array}{l}\text { It is evaluated from the social behavior of birds mitigating flock for reaching the } \\
\text { destination which is not known. }\end{array}$ \\
\hline & 'Particle' is the bird's flock for every solution. \\
\hline & In this, every bird finds a definite solution/direction from the local region. \\
\hline & This process needs social intraction as well as intelligence. \\
\hline \multirow[t]{3}{*}{$\begin{array}{l}\text { Ant Colony optimization } \\
\text { (ACO) }\end{array}$} & $\begin{array}{l}\text { ACO is developed by Dorigo by considering the fact that Ant are able to find the shortest } \\
\text { path from source to destination node. }\end{array}$ \\
\hline & In ACO ants generates n number of processes. \\
\hline & Every Ant is evaluated by using an objective function \\
\hline \multirow{3}{*}{$\begin{array}{l}\text { Artificial Bee Colony } \\
\text { (ABC) }\end{array}$} & It is a swarm inspired algorithm \\
\hline & It mainly comprises of three components: Employed bee, onlooker bee, and Scout bee. \\
\hline & Employed Bee is responsible for searching the food from the hive. \\
\hline
\end{tabular}




\begin{tabular}{|c|c|}
\hline & Onlooker bee is responsible for increasing the quality of the food \\
\hline & Scout Bee is responsible for utilizing employed bee \\
\hline \multirow[t]{5}{*}{$\begin{array}{l}\text { Artificial neural network } \\
\text { (ANN) }\end{array}$} & $\begin{array}{l}\text { It is based on the biological function in whch the relation between input and output are } \\
\text { determined. }\end{array}$ \\
\hline & It works by observing the data sets and provide a better solution. \\
\hline & ANN considered a random data rather than the whole data set \\
\hline & $\begin{array}{l}\text { It comprises of three layes namely input, output and hidden layer that are interconnected } \\
\text { with each other. }\end{array}$ \\
\hline & In the hidden layers weights are attached that modified the results as per the requirement \\
\hline \multirow[t]{5}{*}{ Fuzzy logic } & It is an extension of multilogic function \\
\hline & It works on If and Else statement \\
\hline & It uses membership function to input all fuzzy values \\
\hline & Execute the rules and then provide output by using De-fuzzification \\
\hline & Membership function is used to minimize Boolean logic \\
\hline
\end{tabular}

\section{RELATED WORK}

A comparative analysis has been given in below table.
The table covers environment, techniques used, advantages as well as disadvantages of the work done previously by number of authors.

Table 6. A glance of existing techniques

\begin{tabular}{|c|c|c|c|c|}
\hline References & Environment & Techniques used & Advantages & Outcomes \\
\hline Beloglazov & CLOUD SIM & $\begin{array}{l}\text { MBFD (Modified Best } \\
\text { Fit Decreasing), MM } \\
\text { (Minimization of } \\
\text { Migrations }\end{array}$ & $\begin{array}{c}\text { Less energy } \\
\text { consumption } \\
\text { Cloud computing reduce } \\
\text { the storage of data } \\
\text { center, Load of CPU, } \\
\text { disk has been balanced }\end{array}$ & $\begin{array}{c}\text { The parameters like SLA, } \\
\text { number of VM migrations } \\
\text { has been evaluated }\end{array}$ \\
\hline $\begin{array}{c}\text { M. S. } \\
\text { Pilavare } \\
{[56,2015]}\end{array}$ & CLOUD SIM & Genetic algorithm & $\begin{array}{l}\text { Make spam decreases } \\
\text { Performance increases }\end{array}$ & $\begin{array}{l}\text { Priority has been determined } \\
\text { on the basis of different } \\
\text { algorithm such as Round } \\
\text { Robin, FCFS and GA. }\end{array}$ \\
\hline $\begin{array}{l}\text { M. F. Akbar } \\
\text { et al. [58, } \\
\text { 2016] }\end{array}$ & CLOUD SIM & $\begin{array}{c}\text { Median Deviation based } \\
\text { Task Scheduling } \\
\text { (MDTS), }\end{array}$ & $\begin{array}{c}\text { Reduce makespan } \\
\text { High Quality } \\
\text { performance is obtained }\end{array}$ & $\begin{array}{l}\text { Performance parameters like } \\
\text { make span, SLR, speedup, } \\
\text { efficiency and number of } \\
\text { better quality solution haven } \\
\text { been measured. MDST } \\
\text { algorithm perfrom well than } \\
\text { all other existing algorithms }\end{array}$ \\
\hline Gao & JAVA & $\begin{array}{l}\text { A binpacking and a } \\
\text { MMAS (max-min ant } \\
\text { system) algorithm, Ant } \\
\text { clony optimization }\end{array}$ & $\begin{array}{l}\text { The proposed system is } \\
\text { more efficient and } \\
\text { reliable than other } \\
\text { existing algorithms }\end{array}$ & $\begin{array}{c}\text { The performance parameters } \\
\text { such as Power consumption, } \\
\text { resource wastage, } \\
\text { With respect to correlation } \\
\text { coefficient has been } \\
\text { measured }\end{array}$ \\
\hline Han & CLOUD SIM & $\begin{array}{l}\text { RUA (Remaining } \\
\text { Utilization Aware), PA } \\
\text { (Power aware) }\end{array}$ & $\begin{array}{l}\text { These algorithms are } \\
\text { sued in hybrid for } \\
\text { completing the VM task } \\
\text { in cloud data centre }\end{array}$ & $\begin{array}{l}\text { Prevent server from overload } \\
\text { Reduce SLA violations }\end{array}$ \\
\hline Tsakalozos & CLOUD SIM & $\begin{array}{l}\text { VM migration, Priority } \\
\text { based algorithm }\end{array}$ & $\begin{array}{c}\text { Load sharing } \\
\text { Increase utilization of } \\
\text { physical amchine } \\
\text { High consumption of } \\
\text { task scheduled during } \\
\text { less load }\end{array}$ & $\begin{array}{l}\text { The performance parameter } \\
\text { like SLA violation has been } \\
\text { measuredCost driven policy }\end{array}$ \\
\hline Zhang, & CLOUD SIM & $\begin{array}{c}\text { VM migration, } \\
\text { Clustering algorithm }\end{array}$ & $\begin{array}{l}\text { Effective VM migration } \\
\text { in cloud media } \\
\text { Total internal traffic in } \\
\text { cloud media decreases }\end{array}$ & $\begin{array}{l}\text { The parameters such as total } \\
\text { migration time, total data } \\
\text { transmission, the average } \\
\text { packet exchange frequency }\end{array}$ \\
\hline
\end{tabular}




\begin{tabular}{|c|c|c|c|c|}
\hline & & & are determined \\
\hline Borhani, & CLOUD SIM & $\begin{array}{c}\text { Energy aware VM } \\
\text { migration, MBFD }\end{array}$ & $\begin{array}{c}\text { Minimize SLA violation } \\
\text { Less energy } \\
\text { consumption }\end{array}$ & $\begin{array}{c}\text { The proposed algorithm } \\
\text { achieved SLA violation up to } \\
73 \% \text { and energy consumption } \\
\text { up to 81\%. }\end{array}$ \\
\hline
\end{tabular}

\section{CONCLUSION}

This paper dealt with the current research evaluation on virtualization for the effective utilization of the resources following its categories. VMM is necessary for different reasons, like, energy reduction, load balancing, dynamic resizing as well as enhancing availability. The VM migration assists the effective utilization of having different objectives of resource management. Usually, VMM procedure thoroughly provides the application performance until and unless it is being attended by enhanced optimization techniques. A comparative analysis of work done by number of author has been provided in the review.

\section{REFERENCES}

1. Armbrust, M., Fox, A., Griffith, R., Joseph, A. D., Katz, R., Konwinski, A.,\& Zaharia, M., "A view of cloud computing," Communications of the ACM, vol. 53, no.4, pp.50-58,2010.

2. Qian, L., Luo, Z., Du, Y., \& Guo, L, "Cloud computing: An overview,” Cloud computing, pp. 626-631, 2009.

3. Buyya, R., Yeo, C. S., Venugopal, S., Broberg, J., \& Brandic, I, "Cloud computing and emerging IT platforms: Vision, hype, and reality for delivering computing as the 5th utility," Future Generation computer systems, vol. 25, no.6, pp.599-616,2009.

4. Zhang, Q., Cheng, L., \& Boutaba, R., "Cloud computing: stateof-the-art and research challenges," Journal of internet services and applications, vol. 1, no.1, pp.7-18, 2010.

5. Ostermann, S., Iosup, A., Yigitbasi, N., Prodan, R., Fahringer, T., \& Epema, D, "A performance analysis of EC2 cloud computing services for scientific computing," International Conference on Cloud Computing, Springer, Berlin, Heidelberg, pp. 115-131, 2009.

6. Subashini, S., \& Kavitha, V, “A survey on security issues in service delivery models of cloud computing," Journal of network and computer applications, vol. 34, no. 1,pp. 1-11, 2011.

7. Beloglazov, A., Abawajy, J., \& Buyya, R, "Energy-aware resource allocation heuristics for efficient management of data centers for cloud computing,” Future generation computer systems, vol.28, no.5, pp. 755-768,2012.

8. M. S. Pilavare and A. Desai, "A novel approach towards improving performance of load balancing using Genetic Algorithm in cloud computing," International Conference on Innovations in Information, Embedded and Communication Systems (ICIIECS), Coimbatore, pp. 1-4,2015.

9. M. F. Akbar, E. U. Munir, M. M. Rafique, Z. Malik, S. U. Khan and L. T. Yang, "List-Based Task Scheduling for Cloud Computing," IEEE International Conference on Internet of Things (iThings) and IEEE Green Computing and Communications (GreenCom) and IEEE Cyber, Physical and Social Computing (CPSCom) and IEEE Smart Data (SmartData), Chengdu, pp. 652-659,2016.

10. Gao, Y., Guan, H., Qi, Z., Hou, Y., \& Liu, L, "A multiobjective ant colony system algorithm for virtual machine placement in cloud computing," Journal of Computer and System Sciences, vol.79, no. 8, pp. 1230-1242,2013.

11. Han, G., Que, W., Jia, G., \& Shu, L, "An efficient virtual machine consolidation scheme for multimedia cloud computing," Sensors, vol. 16, no.2,pp. 246,2016.

12. Tsakalozos, K., Verroios, V., Roussopoulos, M., \& Delis, A, "Live VM Migration Under Time-Constraints in Share-Nothing IaaS-Clouds,” IEEE Transactions on Parallel and Distributed Systems, vol. 28, no. 8, pp. 2285-2298,2017.

13. Zhang, W., Chen, Y., Gao, X., Mo, Z., Zheng, Q., \& Lu, Z, "Cluster-Aware Virtual Machine Collaborative Migration in Media Cloud,” IEEE Transactions on Parallel and Distributed Systems,2017.

14. Borhani, A. H., Hung, T., Lee, B. S., Qin, Z., \& Bagheri, Z, "Network-Aware VM Migration Heuristics for Improving the SLA Violation of Multi-Tier Web Applications in the Cloud," Parallel, Distributed and Network-based Processing (PDP), pp. 454-462, 2017.

15. Reuther, Lars, Dustin L. Green, and John A. Starks, "Virtual machine migration techniques," U.S. Patent No. 9,110,702. 18, 2015.

16. Akoush, S., Sohan, R., Rice, A., Moore, A. W., \& Hopper, A, "Predicting the performance of virtual machine migration, In Modeling, Analysis \& Simulation of Computer and Telecommunication Systems (MASCOTS), IEEE International Symposium, pp. 37-46, 2010. 